\title{
Laboratory antimicrobial resistance surveillance: extend spectrum beta lactamase (ESBL) producing $E$. coli
}

\author{
S Mobasherizadeh ${ }^{1 *}$, S Jalalpoor ${ }^{2}$, A Ebneshahidi ${ }^{3}$, L Ghaedi ${ }^{1}$ \\ From International Conference on Prevention \& Infection Control (ICPIC 2011) \\ Geneva, Switzerland. 29 June - 2 July 2011
}

\section{Introduction / objectives}

This study aims to investigate the prevalence of ESBL producing E.coli in urinary tract nosocomial and community acquired infections of Isfahan selected hospitals.

\section{Methods}

The present study was performed at four tertiary care hospitals in Isfahan, Iran. During a 14 month period (Jun, $7^{\text {th }}, 2008$ to July, $\left.6^{\text {th }}, 2010\right) .690$ of Â E.coli isolated from urinary tract infection were studied. 425 of E.coli isolated from community acquired and 265 isolated from nosocomial urinary tract infection were evaluated. Standard microbiological methods were performed(according to CLSI 2006). In order to validate the extended-spectrum beta-lactamases (ESBLs) producing strains were used by disk diffusion method. The collected data was analyzed thorough whonet 5.6 software.

\section{Results}

The prevalence of ESBLs producing E.coli isolated from community acquired urinary tract infection came out to be $17 \%$ and $58 \%$ for urinary tract nosocomial infection respectively $(\mathrm{P}<0.001)$. The antibiotic resistance rates of isolated in nosocomial and community UTIs were $94.9 \%$ and $84.4 \%$ to ampicillin. $(\mathrm{P}<0.01), 59.4 \%$ and $19.7 \%$ to ceftazidime, $64.2 \%$ and $19.8 \%$ to cefotaxime, $62.5 \%$ and $12.2 \%$ to ceftizoxime $60 \%$ and $18.6 \%$ to gentamicin. $(\mathrm{P}<0.001), 17 \%$ and $8.2 \%$ to amikacin , and $40.8 \%$ to Nalidixic acid, $23.1 \%$ and $10.2 \%$ to nitrofurantoin, $47.5 \%$ and $31.4 \%$ to ciprofloxacin and $84.4 \%$ and $60.1 \%$ to trimethoprim/sulfamethoxazole $(\mathrm{p}<0.005)$.

${ }^{1}$ Isfahan University of Medical Sciences, Isfahan, Iran, Islamic Republic of Full list of author information is available at the end of the article

\section{Conclusion}

Establish systems for monitoring antimicrobial resistance in hospitals and the community and link these findings to resistance and disease surveillance data is fundamental to developing treatment guidelines accurately and to assessing the effectiveness of interventions appropriately.

\section{Disclosure of interest}

None declared.

\section{Author details}

'Isfahan University of Medical Sciences, Isfahan, Iran, Islamic Republic of. ${ }^{2}$ Islamic Azad University Shahreza Branch, Isfahan, Iran, Islamic Republic of. ${ }^{3}$ Sadi Hospital, Isfahan, Iran, Islamic Republic of.

Published: 29 June 2011

\section{doi:10.1186/1753-6561-5-S6-P135}

Cite this article as: Mobasherizadeh et al: Laboratory antimicrobial resistance surveillance: extend spectrum beta lactamase (ESBL) producing E. coli. BMC Proceedings 2011 5(Suppl 6):P135.

Submit your next manuscript to BioMed Central and take full advantage of:

- Convenient online submission

- Thorough peer review

- No space constraints or color figure charges

- Immediate publication on acceptance

- Inclusion in PubMed, CAS, Scopus and Google Scholar

- Research which is freely available for redistribution

Submit your manuscript at www.biomedcentral.com/submit

\section{O) Biomed Central}

